\title{
Development and Validation of Stability Indicating RP-HPLC-PDA Method for Tenatoprazole and Its Application for Formulation Analysis and Dissolution Study
}

\author{
Sunil R. Dhaneshwar, Vaijanath N. Jagtap \\ Department of Pharmaceutical Chemistry, Bharati Vidyapeeth University, Poona College of Pharmacy, \\ Maharashtra, India \\ E-mail: sunil.dhaneshwar@gmail.com,vnjagtap@yahoo.co.in \\ Received November 17, 2010; revised January 21, 2011; accepted January 24, 2011
}

\begin{abstract}
In the present study, comprehensive stress testing of tenatoprazole was carried out according to ICH guideline Q1A (R2). Tenatoprazole was subjected to stress conditions of hydrolysis, oxidation, photolysis and neutral decomposition. Extensive degradation was found to occur in acidic, neutral and oxidative conditions. Mild degradation was observed in basic conditions. The drug is relatively stable in the solid-state. Successful separation of drug from degradation products formed under stress conditions was achieved on a Kromasil $\mathrm{C}_{18}$ column $(250 \mathrm{~mm} \times 4.6 \mathrm{~mm}, 5.0 \mu$ particle size) using methanol: THF: acetate buffer $(68: 12: 20 \mathrm{v} / \mathrm{v}) \mathrm{pH}$ adjusted to 6.0 with acetic acid as mobile phase, flow rate was $1.0 \mathrm{~mL} \cdot \mathrm{min}^{-1}$ and column was maintained at $45^{\circ} \mathrm{C}$. Quantification and linearity was achieved at $307 \mathrm{~nm}$ over the concentration range of $0.5-160 \mu \mathrm{g} \cdot \mathrm{mL}^{-1}$ for tenatoprazole. The method was validated for specificity, linearity, accuracy, precision, LOD, LOQ and robustness.
\end{abstract}

Keywords: Stability Indicating RP-HPLC-PDA, Method Validation, Column Liquid Chromatography

\section{Introduction}

Tenatoprazole is a novel proton pump inhibitor which has imidazopyridine ring connected to a pyridine ring by sulfinylmethylchain. Tenatoprazole (Figure 1), 5-methoxy-2-(3,5-dimethyl-4-methoxy)-2-pyridyl]methylthio]-i midazole[4,5-b]pyridine is a prodrug of the proton pump inhibitor (PPI) class, which is converted to the active sulfenamide or sulfenic acid by acid in the secretory canaliculus of the stimulated parietal cell of the stomach [1]. This active species binds to luminally accessible cysteines of the gastric $\mathrm{H}+, \mathrm{K}+$ ATPase resulting in disulfide formation and acid secretion inhibition [2,3]. However, the anti-secretory and anti-ulcer effects of tenatoprazole were reported to be 2 - 4 times more potent than those of omeprazole with long-lasting effects on gastric acid secretion [4]. All proton pump inhibitors are unstable when exposed to an acidic milieu, such as the stomach. Therefore, they are formulated with an enteric coating that shields the active drug from the acidic gastric environment $[5,6]$. Tenatoprazole has a greatly ex- tended plasma half-life in comparison with other proton pump inhibitors [7]. HPLC method for the quantitative determination of tenatoprazole in rat plasma [8], pharmacokinetic study in dog plasma [3-9] and pharmacokinetic study in healthy male Caucasian volunteers [10] have been reported. These methods were developed for the purpose of determining low level of drug substance in the biological samples, thus they are not suitable for routine analysis of formulated product where the content of API is high in the formulation. Recently one stability indicating LC-MS/MS method was reported [11] using $\mathrm{C}_{18}$ column and runtime of $15 \mathrm{~min}$. Large number of samples are generated during stability study therefore

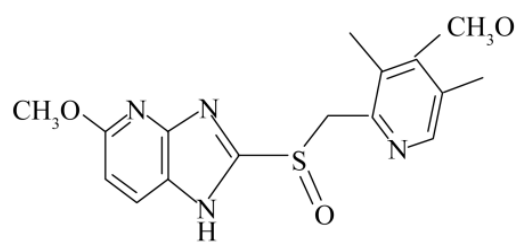

Figure 1. Structure of tenatoprazole. 
stability indicating method with short analysis time is always preferred in order to increase efficiency and for economics of operations. It also requires that analytical test procedures for stability samples should be stability-indicating and should be fully validated [12].

Therefore the aim of the present study was to develop a sensitive, precise, accurate and stability indicating RPHPLC-PDA method with short runtime for the determination of tenatoprazole and further application of the method for dissolution study.

\section{Experimental}

\subsection{Materials and Reagents}

Laboratory formulated tablets from two lots (B. No. SAP 1101, SAP 1102) containing $20 \mathrm{mg}$ of tenatoprazole were used for analysis. Pure drug sample of tenatoprazole (98.5\%) were obtained as a gift sample from New Health Care Ltd. Indore (MP). HPLC grade methanol and tetrahydrofuran (THF) were procured from Merck and Qualigens Fine Chemicals, respectively (Mumbai, India). Analytical grade ammonium acetate and acetic acid were procured from Research Lab Fine Chem. (Mumbai, India). Double distilled water and tablet placebo were made at lab scale only.

\subsection{Instrumentation and Chromatographic Conditions}

The HPLC system consisted of a binary pump (model Waters 515), auto sampler (model 717 plus), column heater, and PDA detector (Waters 2998). Data collection and analysis were performed using Empower-version 2 software. Separation was achieved on Kromasil $\mathrm{C}_{18}$ column $(250 \mathrm{~mm} \times 4.6 \mathrm{~mm}, 5.0 \mu)$ maintained at $45^{\circ} \mathrm{C}$ using column oven. Isocratic elution with methanol: tetrahydrofuran: $25 \mathrm{mM}$ acetate buffer (68:12:20 v/v) mobile phase adjusted to $\mathrm{pH} 6.0$ with acetic acid at the flow rate of $1.0 \mathrm{~mL} \cdot \mathrm{min}^{-1}$ were carried out. The detection was monitored at $307 \mathrm{~nm}$ and injection volume was $20 \mu \mathrm{L}$. The peak purity was checked with the photodiode array detector.

\subsection{Preparation of Standard Solutions and Calibration Curve}

Standard stock solution of tenatoprazole containing 1000 $\mu \mathrm{g} \cdot \mathrm{mL}^{-1}$ were prepared in methanol. To study the linearity range, serial dilutions were made from 0.50 to 160 $\mu \mathrm{g} \cdot \mathrm{mL}^{-1}$ in mobile phase and injected in to column. Calibration curves were plotted as concentration of drug versus peak area response. From the standard stock solutions, solution containing $80 \mu \mathrm{g} \cdot \mathrm{mL}^{-1}$ of tenatoprazole was injected in to column. The system suitability test was performed from six replicate injections of standard solution.

\subsection{Analysis of Tablet Formulations}

Twenty tablets were weighed accurately and a quantity of tablet powder equivalent to $100 \mathrm{mg}$ of tenatoprazole was weighed and dissolved in $80 \mathrm{~mL}$ of methanol with the aid of ultrasonication for $10 \mathrm{~min}$ and solution was filtered through Whatman paper No. 41 into a $100 \mathrm{~mL}$ volumetric flask. Filter paper was washed with the solvent, adding washings to the volumetric flask and volume was made up to mark. The solution was suitably diluted with mobile phase to get a concentration of $80 \mu \mathrm{g} \cdot \mathrm{mL}^{-1}$ of tenatoprazole.

\subsection{Method Validation}

The HPLC method was validated in terms of precision, accuracy and linearity according to ICH guidelines [11]. Assay method precision was determined using nine independent test solutions. The intermediate precision of the assay method was also evaluated as inter-day and intra-day precision. The accuracy of the assay method was evaluated with the recovery of the standards from excipients. Three different quantities (low, medium and high) of the authentic standards were added to the placebo. The mixtures were extracted and analyzed using the developed HPLC method. Linearity test solutions were prepared as described in Section 2.3. The Limit of Detection (LOD) and Limit of Quantification (LOQ) for analytes were estimated by injecting a series of dilute solutions with known concentration. Values of LOD and LOQ were calculated by using $\sigma$ (standard Deviation of response) and $b$ (Slope of the calibration curve) and by using equations, $\mathrm{LOD}=(3.3 \times \sigma) / \mathrm{b}$ and $\mathrm{LOQ}=$ $(10 \times \sigma) / \mathrm{b}$. To determine the robustness of the method, final experimental conditions were purposely altered and results were examined. The parameters considered ( \pm values) for the study were, flow rate $( \pm 5 \%)$, column temp. $\left( \pm 2^{\circ} \mathrm{C}\right)$, measurement wavelength $( \pm 1 \mathrm{~nm})$, injection volume $( \pm 2 \mu \mathrm{l})$, \% organic $( \pm 5 \%)$, buffer strength $( \pm 5 \mathrm{mM})$ and effect of column from different lots were studied. The drug solution stability were carried out for short-term stability by keeping at room temperature for 12 hrs, long-term stability by storing at $4^{\circ} \mathrm{C}$ for 30 days and auto-sampler stability by storing the samples for 24 hrs in the auto-sampler and then analyzing against freshly prepared solutions. For method development and optimization, retention factor $(k)$ were calculated by using parameters $t_{R}$ (retention time) and $t_{M}$ (elution time of the solvent front) and by using the equation $k=\left(t_{R}-t_{M}\right) / t_{M}$. 


\subsection{Dissolution Study}

A calibrated dissolution apparatus (USP II) were used with paddles at $50 \mathrm{rpm}$ and bath temperature maintained at $(37 \pm 1)^{\circ} \mathrm{C}, 450 \mathrm{ml} 0.1 \mathrm{~N} \mathrm{HCl}$ were used as dissolution medium. During dissolution study $5 \mathrm{ml}$ of sample (with replacement) were removed from each vessel. Samples were removed after every $5 \mathrm{~min}$ for $45 \mathrm{~min}$. Sample were filtered through a nylon membrane filter $(0.45 \mu \mathrm{m}, 25 \mathrm{~mm})$, $2.5 \mathrm{ml}$ of filtrate were diluted to $5 \mathrm{ml}$ with mobile phase and analyzed by the proposed method. The amount of tenatoprazole in the test samples were calculated as percentage dissolved, from the measured peak area for the test samples by using Equation (1). Alternatively area of sample were calculated and compared it with the peak area for the standard (std.) solution using Equation (2).

Dissolved $(\%)=($ Conc. calculated by using linear equation $\times$ 900/DL)

Dissolved $(\%)=(900 / \mathrm{DL}) \times($ Peak Area $($ sample $) /$ Peak Area (std.)) $\times$ Conc. (std.) $\times 100$

where $\mathrm{DL}=$ drug load, which is $20 \mathrm{mg}$ of tenatoprazole.

\subsection{Method Specificity (Forced Degradation Study)}

Forced degradation of the drug and drug product were carried out under thermolytic, photolytic, acid/base hydrolytic and oxidative stress conditions. For photolytic stress, drug product in the solid state were irradiated with UV radiation at 254 and $366 \mathrm{~nm}$. The UV dose from the lamp at $366 \mathrm{~nm}$ were measured by use of a quinine monohydrochloride ( $2 \%$ solution in water) chemical actinometer as mentioned in the ICH guidelines [10]. Minimum desired exposure $\left(200 \mathrm{Wh} / \mathrm{m}^{2}\right)$ were observed after irradiation for $26 \mathrm{~h}$. A second photolytic stress test experiment with greater irradiation time, $52 \mathrm{~h}$, were performed to establish the specificity of the method. Sample solution containing $2000 \mathrm{mg} \cdot \mathrm{mL}^{-1}$ were subjected to selected stressed conditions, appropriately diluted and injected into column. Samples except for photo oxidation were protected from light. For acid, base and water-induced degradation solutions containing $2000 \mathrm{mg} \cdot \mathrm{mL}^{-1}$ of the drug were prepared in $0.1 \mathrm{~N} \mathrm{HCl}, 0.1 \mathrm{~N} \mathrm{NaOH}$ and water, heated on constant water bath at $80^{\circ} \mathrm{C}$ and analyzed after 1,2 and $12 \mathrm{~h}$ exposure, respectively. For oxidative degradation solution were prepared in water containing $30 \% \mathrm{v} / \mathrm{v}$ of $\mathrm{H}_{2} \mathrm{O}_{2}$, heated on constant water bath at $80^{\circ} \mathrm{C}$ and analysed after $1 \mathrm{~h}$.

\subsection{Photochemical Degradation and Dry Heat Degradation}

Photochemical stability of the drug were studied by exposing stock solution $\left(2000 \mu \mathrm{g} \cdot \mathrm{mL}^{-1}\right)$ as well as solid drug to short UV and long UV radiations for $26 \mathrm{~h}$ and were used. For dry heat degradation drug in solid form were placed in oven at $60^{\circ} \mathrm{C}$ for 8 hours and used to prepare solution. The solutions were diluted with mobile phase to have $80 \mu \mathrm{g} \cdot \mathrm{mL}^{-1}$ and $20 \mu \mathrm{L}$ of the solution were injected into the system.

\section{Results and Discussion}

\subsection{Optimization of the Chromatographic Conditions (Method Development)}

The HPLC procedure were optimized with a view to develop stability-indicating assay method. Pure drug along with its degraded products were injected and run in different solvent systems. Initially methanol and water in different ratios were tried. It were found that when methanol concentration were increased in the mobile phase, the degradation product started to elute in dead volume. Hence concentration of methanol was decreased and there was improvement in resolution. It was found that mobile phase consisting of methanol: THF: acetate buffer $(68: 12: 20 \mathrm{v} / \mathrm{v}) \mathrm{pH}$ adjusted to 6.0 with acetic acid, flow rate were $1.0 \mathrm{~mL} \cdot \mathrm{min}^{-1}$ gives acceptable retention time of $3 \mathrm{~min}$. $\left(t_{R}\right)$, theoretical plates and good resolution of drug and degradation products (Figure 2).

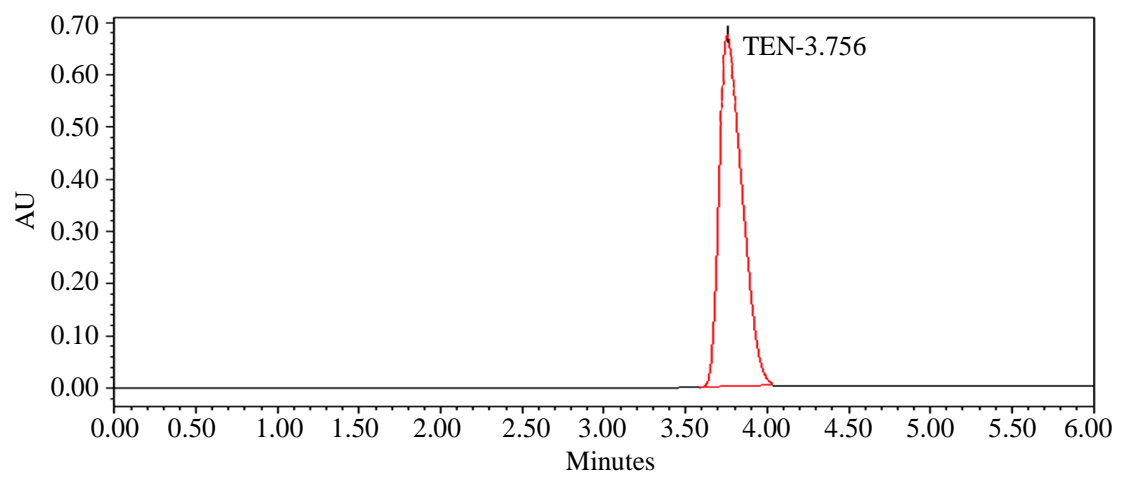

Figure 2. Tenatoprazole $100 \mu \mathrm{g} \cdot \mathrm{mL}^{-1}$ standard chromatogram. 
Well defined symmetrical peaks were obtained upon measuring the response of eluent under the optimized conditions after thorough experimental trials. Two columns were used for performance investigations, including Kromasil $\mathrm{C}_{18}(4.6 \times 250 \mathrm{~mm}, 5$ micron) and Symmetry $\mathrm{C}_{18}(4.6 \times 250 \mathrm{~mm}, 5$ micron$)$, Symmetry $\mathrm{C}_{18}$ showed broad, unsymmetrical peak therefore it were replaced with Kromasil $\mathrm{C}_{18}$ column which produced symmetrical peaks with good resolution. The UV detector response of tenatoprazole was studied and the best wavelength was found to be $307 \mathrm{~nm}$ showing highest sensitivity.

\subsection{Method Validation}

The method was validated, in accordance with ICH guidelines, for linearity, range, accuracy, precision, LOD and LOQ, specificity, ruggedness and robustness [11].

\subsubsection{Linearity and Range}

For the construction of calibration curves, seven calibration standard solutions were prepared over the concentration range. Linearity was determined for tenatoprazole in the range of $0.5-160 \mu \mathrm{g} \cdot \mathrm{mL}^{-1}$. The correlation coefficient (' $\mathrm{r}^{2}$ ) $)$ values were $>0.999(\mathrm{n}=6)$. Typically, the regression equations for the calibration curve was found to be $y=68800 \times(-77500)$ (Figure 2).

\subsubsection{Formulation Analysis and Accuracy}

System suitability test were performed every time before formulations analysis (Table 1). Formulations were ana-

Table 1. System suitability parameters.

\begin{tabular}{cc}
\hline Parameter & Values \pm SD \\
\hline No of theoretical plates (SD) & $2670 \pm 30$ \\
USP Tailing Factor (SD) & $1.38 \pm 0.02$ \\
Capacity factor & $2.8 \pm 0.02$ \\
Typical Peak Purity angle & 0.121 \\
Typical Purity threshold & 0.245 \\
\hline
\end{tabular}

lysed as described in experimental section. Assay values were $(100 \pm 0.8) \%$ for both the formulations accuracy of the method were calculated by recovery studies at three levels by standard addition method. Results of formulation analysis and accuracy studies are presented in Table 2.

\subsubsection{Precision}

The precision of repeatability were studied by replicate $(n=6)$ analysis of tablet solutions. The precision was also studied in terms of intra-day changes in peak area of drug solution on the same day and on three different days over a period of one week. The intra-day and inter-day variation were calculated in terms of percentage relative standard deviation and the results are summarized in Table 3.

\subsubsection{Limit of Detection (LOD) and Limit of Quantitation (LOQ)}

The LOD and LOQ values were found to be 0.49 and $1.50 \mu \mathrm{g} \cdot \mathrm{mL}^{-1}$, respectively. Low values of these parameter indicates sensitivity of the method.

\subsubsection{Robustness}

Robustness was studied as described in Section 2.5, \% R.S.D. of assay was calculated for each condition. The degree of reproducibility of the results obtained as a result of small deliberate variations in the method parameters has proven that the method is robust and the results are summarized in Table 4.

Table 2. Results of tablet analysis and accuracy studies.

\begin{tabular}{|c|c|c|c|c|}
\hline \multirow{2}{*}{$\begin{array}{l}\text { Tablet Label } \\
\text { Claim }\end{array}$} & \multicolumn{2}{|c|}{$\begin{array}{l}\text { Formulation } \\
\text { Study }(n=6)\end{array}$} & \multicolumn{2}{|c|}{$\begin{array}{l}\text { Recovery (accuracy) } \\
\text { Study }(\mathrm{n}=3)\end{array}$} \\
\hline & $\begin{array}{l}\text { Tablet } \\
\text { Batch }\end{array}$ & $\begin{array}{c}\text { \% Assay Found, } \\
\text { \% RSD }\end{array}$ & $\begin{array}{c}\text { Recovery } \\
\text { Level }\end{array}$ & $\begin{array}{c}\text { \% Recovery, } \\
\text { \% RSD }\end{array}$ \\
\hline \multirow{3}{*}{$\begin{array}{l}\text { Tenatoprazole } \\
\text { 20mg }\end{array}$} & SAP 1101, & $99.74,1.05$ & 50 & $99.68,0.67$ \\
\hline & \multirow{2}{*}{ SAP 1102} & \multirow{2}{*}{$100.61,1.23$} & 100 & $100.10,0.24$ \\
\hline & & & 150 & $101.83,0.56$ \\
\hline
\end{tabular}

Table 3. Result of precision study.

\begin{tabular}{ccc}
\hline & \multicolumn{2}{c}{ Estimated amount, \% RSD at selected concentration level } \\
\cline { 2 - 3 } Precision Study Parameter & $10 \mu \mathrm{g} \cdot \mathrm{mL}^{-1}$ & $80 \mu \mathrm{g} \cdot \mathrm{mL}^{-1}$ \\
\hline Repeatability, $\mathrm{n}=6$ & $100.2,0.38$ & $101.4,0.33$ \\
Intra-day, $\mathrm{n}=3$ & $100.8,0.55$ & $99.6,0.51$ \\
Inter-day, $\mathrm{n}=3$ & $98.9,1.13$ & $101.3,0.76$ \\
Analyst, $\mathrm{n}=3$ & $99.5,0.38$ & $100.4,1.06$ \\
\hline
\end{tabular}


Table 4. Result of robustness study.

\begin{tabular}{|c|c|c|c|c|c|}
\hline \multirow{2}{*}{ Parameter (Limit) } & \multirow{2}{*}{ Level } & \multicolumn{3}{|c|}{ System Suitability Parameters $( \pm S D) n=3$} & \multirow{2}{*}{$\%$ Assay, $\%$ RSD, $n=3$} \\
\hline & & $t_{R}$ & $\mathrm{~N}$ & $\mathrm{~K}$ & \\
\hline \multirow{2}{*}{$\begin{array}{l}\text { Flow rate, } \mathrm{mL}^{-1} \cdot \mathrm{min} \\
\quad( \pm 0.1 \mathrm{~mL})\end{array}$} & $(-) 0.90$ & $3.87 \pm 0.022$ & $2650 \pm 22$ & $2.79 \pm 0.024$ & $98.54,1.07$ \\
\hline & $(+) 1.1$ & $3.77 \pm 0.021$ & $2660 \pm 24$ & $2.82 \pm 0.026$ & $99.67,0.54$ \\
\hline \multirow{2}{*}{$\begin{array}{c}\% \text { of Organic } \\
\quad( \pm 5 \%)\end{array}$} & $(-) 63$ & $3.79 \pm 0.026$ & $2670 \pm 32$ & $2.79 \pm 0.032$ & $100.43,1.03$ \\
\hline & $(+) 73$ & $3.82 \pm 0.023$ & $2680 \pm 36$ & $2.80 \pm 0.028$ & $101.43,1.04$ \\
\hline \multirow{2}{*}{$\begin{array}{l}\mathrm{pH} \text { of Mobile Phase } \\
( \pm 0.1)\end{array}$} & $(-) 5.9$ & $3.79 \pm 0.019$ & $2690 \pm 38$ & $2.79 \pm 0.029$ & 100.76, 0.75 \\
\hline & (+) 6.1 & $3.81 \pm 0.024$ & $2658 \pm 36$ & $2.78 \pm 0.033$ & $100.54,0.95$ \\
\hline \multirow{2}{*}{$\begin{array}{l}\text { Column form } \\
\text { different suppliers }\end{array}$} & $\mathrm{CI}^{\mathrm{a}}$ & $3.76 \pm 0.022$ & $2660 \pm 34$ & $2.80 \pm 0.025$ & $100.45,1.08$ \\
\hline & $\mathrm{CII}^{\mathrm{b}}$ & $3.79 \pm 0.024$ & $2680 \pm 32$ & $2.82 \pm 0.026$ & $101.76,1.16$ \\
\hline \multirow{2}{*}{$\begin{array}{l}\text { Wavelength } \\
\qquad( \pm 1 \mathrm{~nm})\end{array}$} & $(-) 306$ & $3.84 \pm 0.022$ & $2670 \pm 28$ & $2.79 \pm 0.022$ & $98.87,1.32$ \\
\hline & (+) 308 & $3.81 \pm 0.026$ & $2680 \pm 30$ & $2.81 \pm 0.032$ & $98.91,1.22$ \\
\hline \multirow{2}{*}{$\begin{array}{l}\text { Buffer strength } \\
\quad( \pm 5 \mathrm{mM})\end{array}$} & (-) 20 & $3.81 \pm 0.019$ & $2670 \pm 26$ & $2.80 \pm 0.028$ & $101.45,0.34$ \\
\hline & $(+) 30$ & $3.82 \pm 0.024$ & $2690 \pm 32$ & $2.82 \pm 0.029$ & $101.55,0.44$ \\
\hline \multirow{2}{*}{$\begin{array}{l}\text { Column Temp. } \\
\qquad\left( \pm 2^{\circ} \mathrm{C}\right)\end{array}$} & $(-) 43$ & $3.77 \pm 0.022$ & $2670 \pm 28$ & $2.80 \pm 0.021$ & $99.45,0.98$ \\
\hline & $(+) 47$ & $3.78 \pm 0.026$ & $2690 \pm 33$ & $2.79 \pm 0.027$ & $98.55,1.02$ \\
\hline
\end{tabular}

a \& b Kromasil C 18 columns from different lots; $t_{R}=$ retention time, $\mathrm{N}=$ no of theoretical plates, $\mathrm{K}=$ Capacity factor.

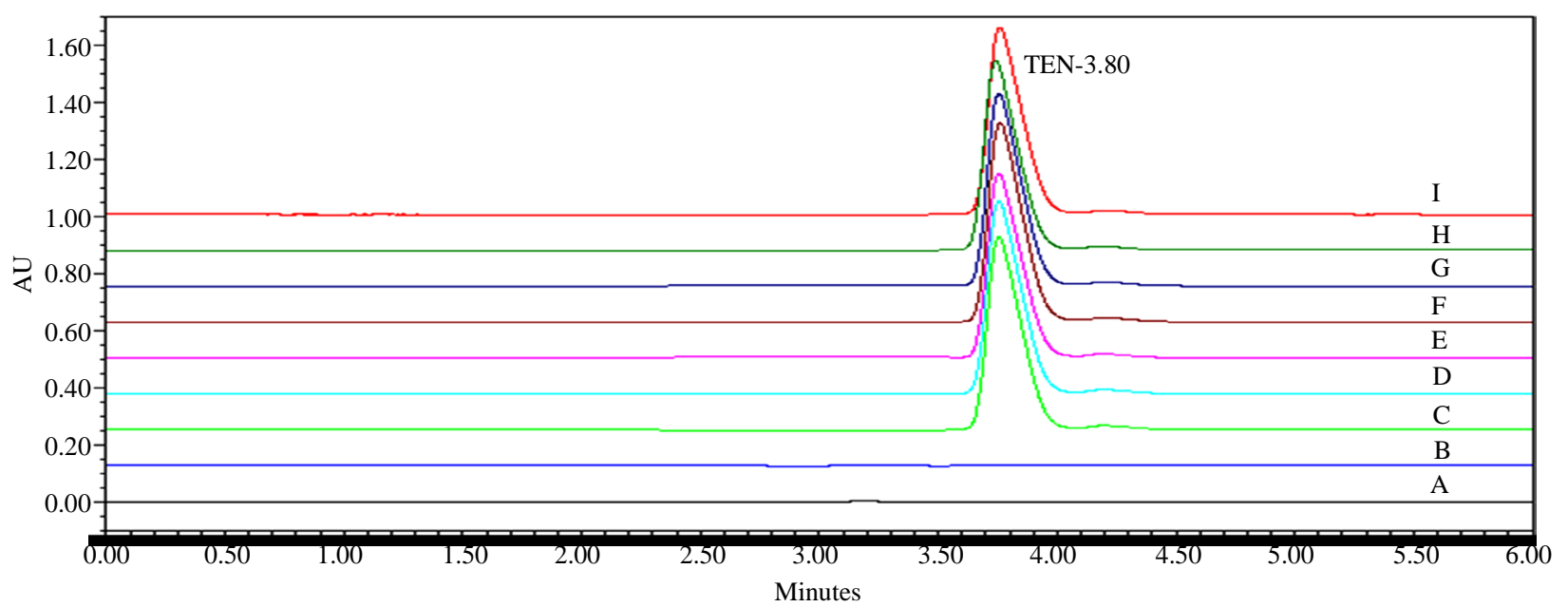

Figure 3. Specificity Chromatogram consists of A) Mobile Phase, B) Placebo, C) Formulation, D) Standard tenatoprazole, E-I) system suitability sample.

\subsubsection{Specificity}

The specificity of the HPLC method is illustrated in Figure 3, where complete separation of tenatoprazole was noticed in presence of placebo. In addition, there was no any interference at the retention time of tenatoprazole in the chromatogram of tablet solution. There was complete separation of all the degraded products under all the stress conditions studied (Figures 4-9) as presented in Table 5. In peak purity analysis with photo diode array detector, purity angle was always less than purity threshold for all the stress conditions. This shows that the peak of analytes was pure and excipients in the formulation and stress degraded products did not interfere.

\subsubsection{Dissolution}

Dissolution was carried out as described in Section 2.6.4, dissolution profile was found to be according to the guidelines and there was a steady and stable release rate with $85 \%$ - 90\% amount released within 40 min (Table 6, Figure 10). 


\subsubsection{Solution Stability Studies}

Solution stability as described in Section 2.5 were performed. Result of short-term, long-term and the auto sampler stability of tenatoprazole solutions were calculated from nominal concentrations and found concentration. All the time results of the stability studies were within the acceptable limit (98\% - 102\%).

\section{Conclusions}

Linear, precise, and accurate RP-HPLC-PDA method has been developed and validated for quantitative determination of tenatoprazole from tablet formulations. All the parameters met the criteria of ICH guidelines for method validation. The method is very simple, specific, reliable,

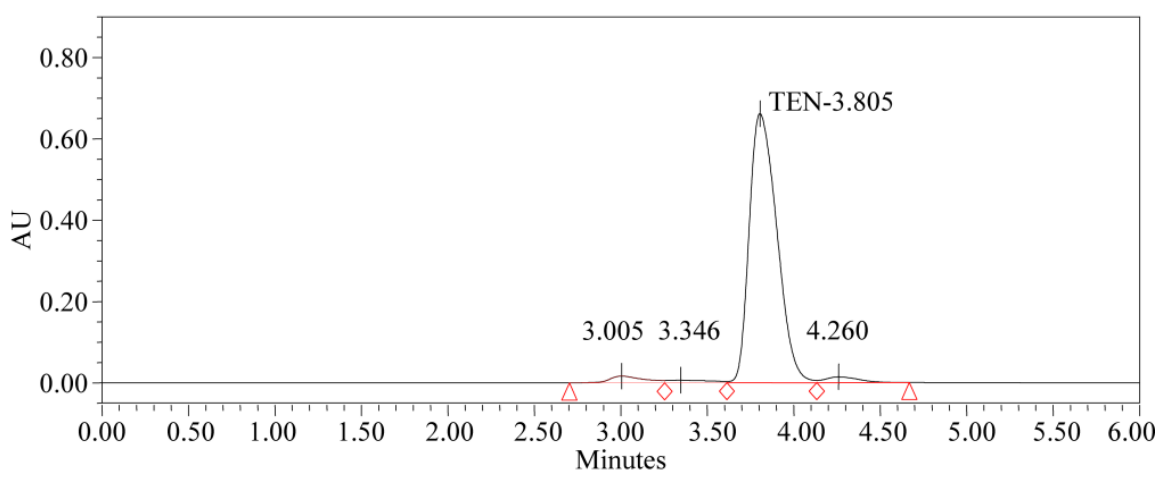

Figure 4. Degradation chromatogram of tenatoprazole in 0.1N HCL.

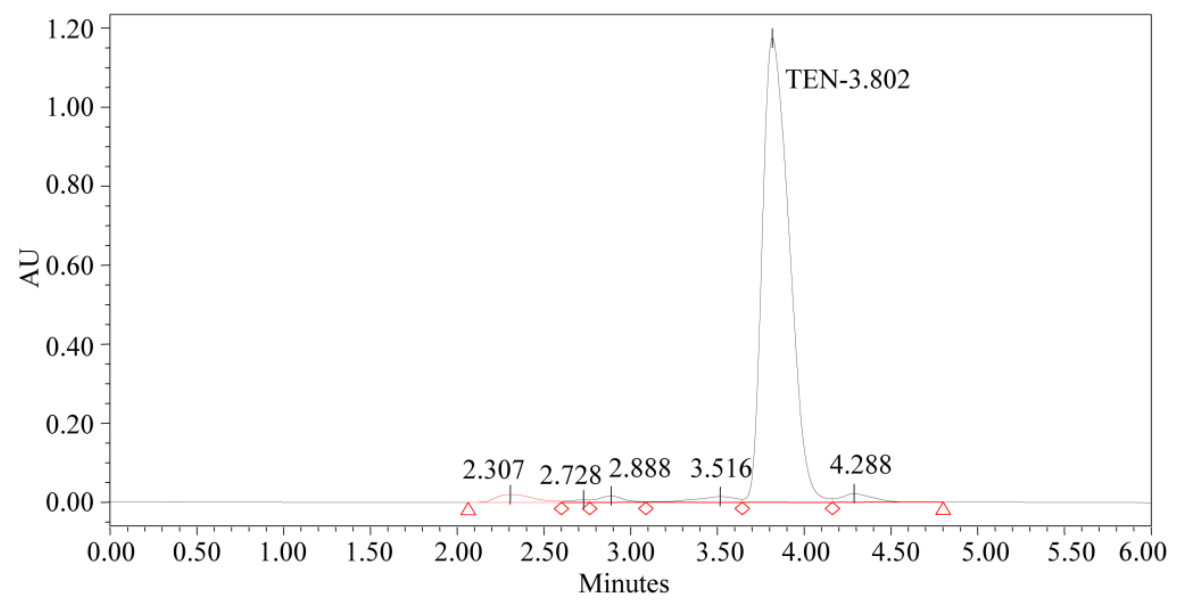

Figure 5. Degradation chromatogram of tenatoprazole in $0.1 \mathrm{~N} \mathrm{NaOH}$.

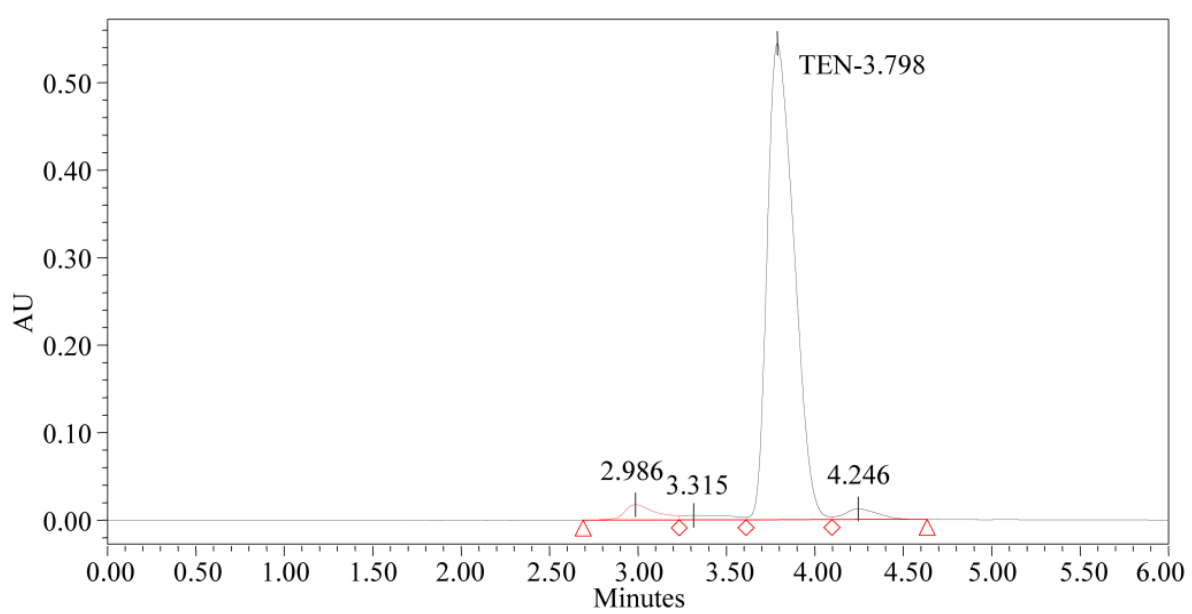

Figure 6. Degradation chromatogram of tenatoprazole in $30 \% \mathrm{H}_{2} \mathrm{O}_{2}$. 


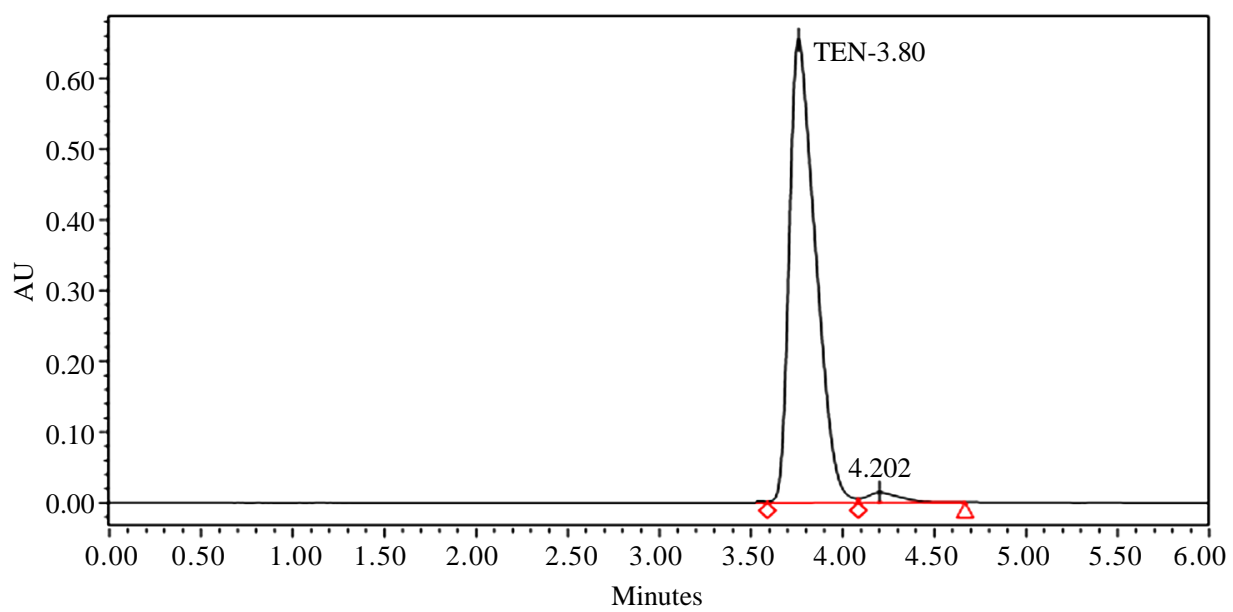

Figure 7. Degradation chromatogram of tenatoprazole at short UV range (254 nm).

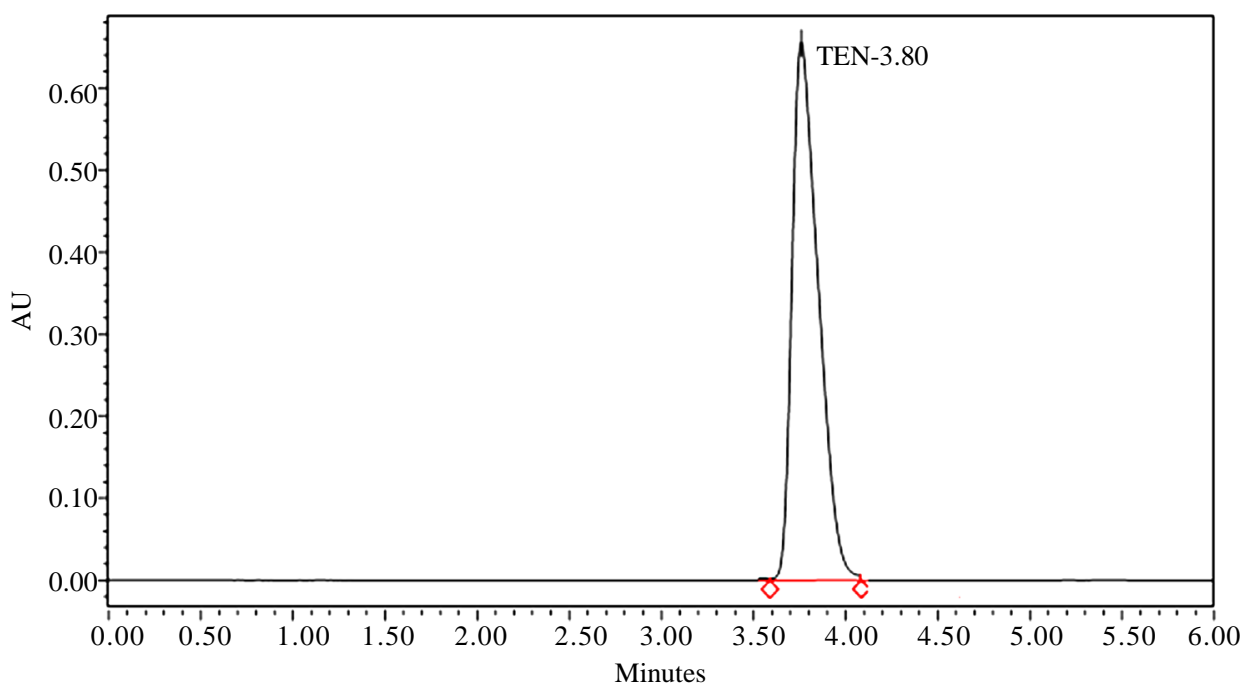

Figure 8. Degradation chromatogram of tenatoprazole at long UV range (366 nm).

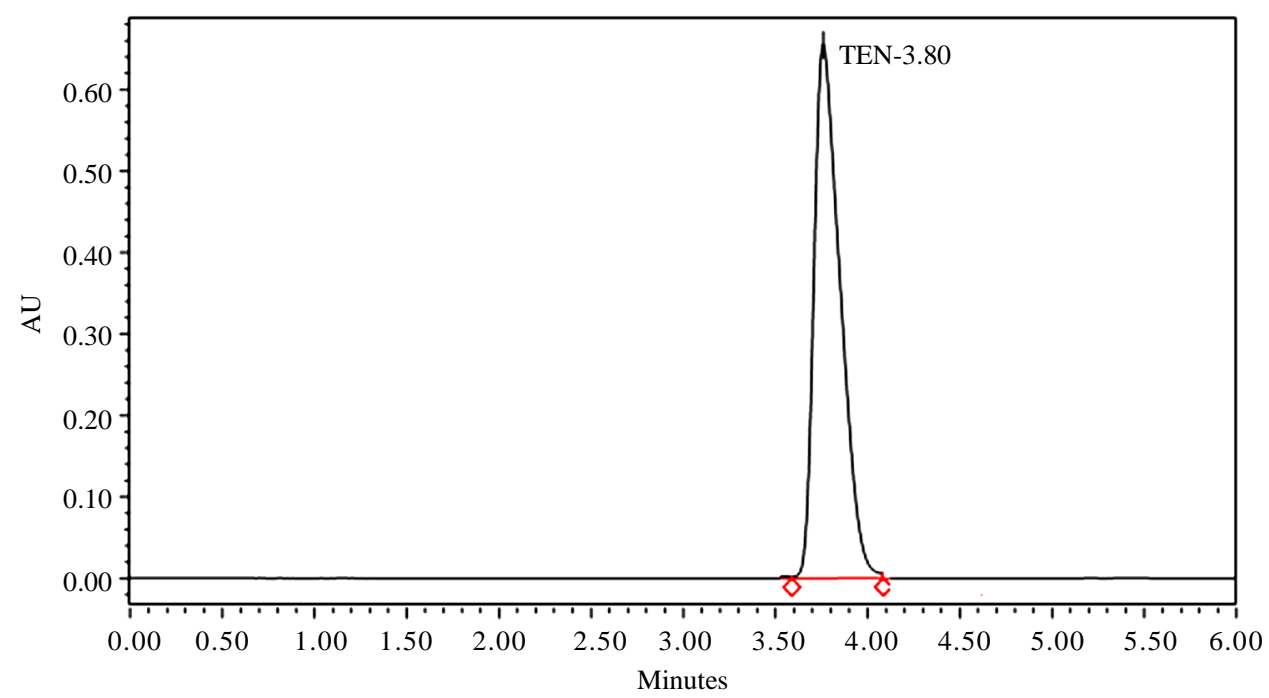

Figure 9. Degradation chromategram of tenatoprazole at dry heat degradation $50^{\circ} \mathrm{C}$ for 4 hrs. 
Table 5. Result of stress degradation study.

\begin{tabular}{|c|c|c|c|c|}
\hline \multirow{2}{*}{ Stress condition } & \multirow{2}{*}{ Degraded products reported at $t_{R}$} & \multirow{2}{*}{ \% Recovery } & \multicolumn{2}{|c|}{ Peak purity } \\
\hline & & & purity angle & purity threshold \\
\hline $2 \mathrm{ml}$ of $0.1 \mathrm{~N} \mathrm{HCl}, 1 \mathrm{~h}$ & $3.005,3.346,4.260$ & 75.67 & 0.247 & 0.415 \\
\hline $2 \mathrm{ml}$ of $0.1 \mathrm{~N} \mathrm{NaOH}, 2 \mathrm{~h}$ & $2.307,2.728,2.888,3.516,4.288$ & 93.2 & 0.278 & 0.389 \\
\hline $2 \mathrm{ml}$ of $30 \% \mathrm{H}_{2} \mathrm{O}_{2}, 1 \mathrm{~h}$ & $2.986,3.315,4.246$ & 78.5 & 0.403 & 0.638 \\
\hline Short UV - 254 nm, 26 h & 4.202 & 96.45 & 0.189 & 0.278 \\
\hline Long UV - 366 nm, 26 h & No degradation peak observed & -- & 0.289 & 0.356 \\
\hline Wet heat - $12 \mathrm{~h}$ & No degradation peak observed & -- & 0.137 & 0.267 \\
\hline Dry heat $-60^{\circ} \mathrm{C}, 8 \mathrm{~h}$ & No degradation peak observed & -- & 0.265 & 0.315 \\
\hline
\end{tabular}

Table 6. Dissolution study data $(n=6)$.

\begin{tabular}{cc}
\hline Time in min. & \% Tenatoprazole Dissolved \\
\hline 5 & 10 \\
10 & 25 \\
15 & 38 \\
20 & 55 \\
25 & 79 \\
30 & 86 \\
35 & 90 \\
40 & 95 \\
45 & 97 \\
50 & 99 \\
\hline
\end{tabular}

rapid and economic as all peaks are well separated and there is no interference by excipients peaks with total runtime of $5 \mathrm{~min}$, which makes it especially suitable for routine quality control analysis work. Stability indicating method with short runtime, simple mobile and MS compatible mobile phase and application of the method for dissolution study is an added advantage. The method were validated according to ICH guidelines and was found to be reproducible.

\section{Acknowledgements}

The authors are grateful to New Health Care Ltd. Indore (MP) for providing gift sample of tenatoprazole.

\section{References}

[1] C. Scarpignato and I. Pelosini, "Review Article: The Opportunities and Benefits of Extended Acid Suppression Aliment," Pharmacology and Therapeutics, Vol. 23, No. S2, 2006, pp. 23-34.

[2] J. Guan, J. Yang, Y. Bi, S. Shi and F. Li, “Chiral Separa-

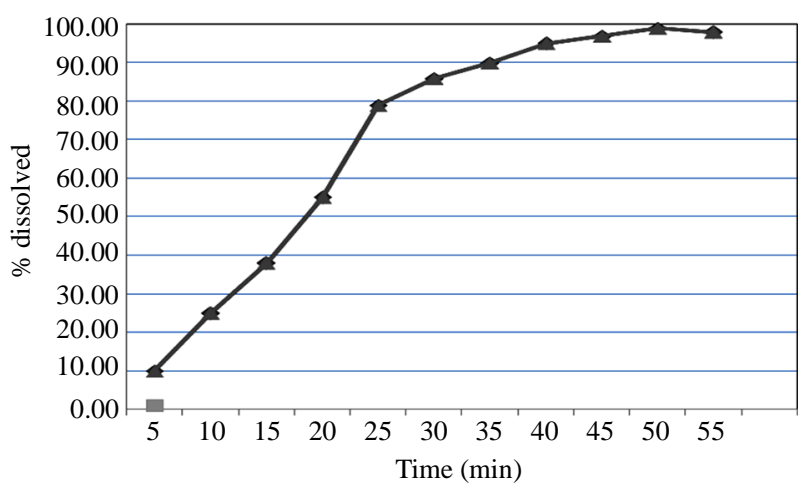

Figure 10. Dissolution profile of tenatoprazole in $0.1 \mathrm{~N} \mathrm{HCl}$ by proposed method.

tion of Tenatoprazole Enantiomers Using High Performance Liquid Chromatography on Vacomycin-Bonded Chiral Stationary Phase,” Se Pu, Vol. 25, No. 5, 2007, pp. 732-734.

[3] K. Uchiyama, D. Wakatsuki, B. Kakinoki, Y. Takeuchi, T. Araki and Y. Morinaka, "The Long-Lasting Effect of TU-199, a Novel H+, K+ -ATPase Inhibitor, on Gastric Acid Secretion in Dogs," Journal of Pharmacy and Pharmacology, Vol. 51, No. 4, 1999, pp. 457-464. doi:10.1211/0022357991772510

[4] A. H. Chun, K. Erdman, Y. Zhang, R. Achari and J. H. Cavanaugh, "Effect on Bioavailability of Admixing the Contents of Lansoprazole Capsules with Selected Soft Foods," Clinical Therapeutics, Vol. 22, No. 2, 2000, pp. 231-236. doi:10.1016/S0149-2918(00)88481-7

[5] C. Larson, N. J. Cavuto, D. A. Flockhart and R. B. Weinberg, "Bioavailability and Efficacy of Omeprazole Given Orally and by Nasogastric Tube,” Digestive Diseases and Sciences, Vol. 41, No. 3, 1996, pp. 475-479. doi:10.1007/BF02282321

[6] J. P. Galmiche, S. B. des Varannes, P. Ducrotte, S. Sacher-Huvelin, F. Vavasseur, A. Taccoen, P. Fiorentini and M. Homerin, "Tenatoprazole, a Novel Proton Pump Inhibitor with a Prolonged Plasma Half-Life: Effects on Intragastric $\mathrm{pH}$ and Comparison with Esomeprazole in 
Healthy Volunteers,” Aliment Pharmacology and Therapeutics, Vol. 19, No. 6, 2004, pp. 655-662. doi:10.1111/j.1365-2036.2004.01893.x

[7] R. Nirogi, V. Kandikere, K. Mudigonda and G. Bhyrapuneni, "Quantification of Tenatoprazole in Rat Plasma by HPLC: Validation and Its Application to Pharmacokinetic Studies,” Biomedical Chromatography, Vol. 21, No. 12, 2007, pp. 1240-1244.doi:10.1002/bmc.875

[8] P. Liu, B. Sun, X. Lu, F. Qin and F. Li, "HPLC Determination and Pharmacokinetic Study of Tenatoprazole in Dog Plasma after Oral Administration of Enteric-Coated Capsule," Biomedical Chromatography, Vol. 21, No. 1, 2007, pp. 89-93. doi:10.1002/bmc.724

[9] F. Domagala, H. Ficheux, G. Houin and J. Barre, "Pharmacokinetics of Tenatoprazole, a Newly Synthesized proton Pump Inhibitor, in Healthy Male Caucasian Vlunteers,” Arzneimittel Forschung, Vol. 56, 2006, pp. 33-39.

[10] M. Mahadik, V. Bhusari, M. Kulkarni and S. Dhaneshwar, "LC-UV and LC-MS Evaluation of Stress Degradation Behavior of Tenatoprazole," Journal of Pharmaceutical and Biomedical Analysis, Vol. 50, No. 5, 2009, pp. 787-793. doi:10.1016/j.jpba.2009.06.026

[11] ICH, "Q2 (R1) Validation of Analytical Procedures: Text and Methodology," International Conference on Harmonization, Geneva, November 2005, pp. 1-13.

[12] P. Lindberg, A. Brandstrom, B. Wallmark, H. Mattsson, L. Rikner and K. J. Hoffmann, "Omeprazole: The First Proton Pump Inhibitor,” Medical Care Research and Review, Vol. 10, No. 1, 1990, pp. 1-54. 